doi: $10.2306 /$ scienceasia1513-1874.2013.39.449

\title{
Efficient adventitious shoot regeneration from shoot tip culture of Vanda coerulea, a Thai orchid
}

\author{
Nipawan Jitsopakul ${ }^{\mathrm{a}}$, Kanchit Thammasiri ${ }^{\mathrm{b}, *}$, Keiko Ishikawa $^{\mathrm{c}}$ \\ a Department of Agro-Industry, Faculty of Agriculture and Technology, \\ Rajamangala University of Technology Isan, Surin Campus, Surin 32000 Thailand \\ b Department of Plant Science, Faculty of Science, Mahidol University, Bangkok 10400 Thailand \\ c Department of Research and Development, Japan Horticultural Production and Research Institute, \\ Chiba 270-2221, Japan
}

*Corresponding author, e-mail: kanchitthammasiri@gmail.com

Received 13 Dec 2012

Accepted 20 May 2013

\begin{abstract}
Vanda coerulea is a popular albeit endangered blue orchid of Thailand, which would be desirable to propagate using regeneration methods. Here, we studied the effects of culture media (Vacin and Went, and Murashige and Skoog), sucrose concentrations (0-30 g/l), and plant growth regulators (BA, TDZ, and NAA) on adventitious shoot regeneration from shoot tip culture of $V$. coerulea. Shoot tips cultured on modified Vacin and Went (VW) medium supplemented with $10 \mathrm{~g} / \mathrm{l}$ sucrose showed higher shoot and root formations, as well as plantlet height than those cultured on Murashige and Skoog medium. Addition of $1 \mathrm{mg} / \mathrm{l} \mathrm{BA}$ to the modified VW medium induced the best shoots and roots after 3 months of culture. The combination of $0.5 \mathrm{mg} / \mathrm{l} \mathrm{NAA}$ and $2 \mathrm{mg} / \mathrm{l} \mathrm{TDZ}$ gave the optimal number of roots per explant and plantlet height after 3 months of culture. Survival rate of plantlets cultured in the greenhouse was $100 \%$ after 3 months of culture. There were no differences in morphology or patterns of ploidy level between stock plants and regenerated plants.
\end{abstract}

KEYWORDS: VW, MS, BA, TDZ, NAA

\section{INTRODUCTION}

Vanda coerulea Griff. ex Lindl., known as blue orchid is the most popular Vanda species of Thailand. It is distributed in Northeast India, South China, Myanmar and Thailand. In Thailand, V. coerulea has a scattered distribution over $500 \mathrm{~km}$ range from western (Kanchanaburi province) to northern (Chiang Mai province) provinces. V. coerulea has become endangered because of environmental changes, deforestation, and wild orchid trade. It was included in Appendix I of the Convention on International Trade in Endangered Species of Wild Fauna and Flora (CITES) since 1979 and then was transferred from Appendix I to Appendix II in 2005. It has a slow growth rate and is used in breeding programs to obtain blue-flowered vandaceous orchid hybrids; hence the numbers are decreasing in the natural habitats ${ }^{1}$. Rapid propagation through tissue culture of $V$. coerulea is therefore urgently needed.

$V$. coerulea has been successfully cultured by using shoot tips and leaf base explants on Mitra, Prasad, and Roy medium ${ }^{2}$ supplemented with $8.8 \mu \mathrm{M}$ 6-benzylaminopurine (BA) and $4.1 \mu \mathrm{M} \alpha$-naphthalene acetic acid (NAA) ${ }^{3}$. Malabadi, Mulgund, and
Nataraja ${ }^{4}$ cultured thin shoot tip sections on Vacin and Went (VW) medium ${ }^{5}$ supplemented with $11.35 \mu \mathrm{M}$ thidiazuron (TDZ) to produce protocorm-like bodies which later develop into shoots with 2-3 leaves. Shoots did produce roots when cultured on half strength VW medium supplemented with $11.42 \mu \mathrm{M}$ indole-3-acetic acid (IAA). However, these methods did not produce shoots and roots when culturing in the same medium. The objectives of this study were to examine the effects of media, concentrations of sucrose, cytokinins (BA and TDZ), and auxin (NAA) on shoot and root formations from shoot tip culture of $V$. coerulea to make an efficient adventitious shoot regeneration protocol.

\section{MATERIALS AND METHODS}

\section{Plant material}

Mature fruits from selfing of $V$. coerulea, harvested at 7 months after pollination, were used for this study. Fruits were cleaned to remove dead tissue, wiped with $70 \%$ ethyl alcohol and then brought inside a laminar air-flow cabinet, soaked in $95 \%$ ethyl alcohol for $1 \mathrm{~min}$ and flamed with lamp until the flame stopped. Fruits were cut and seeds were removed from the 
fruits and then were sown on modified VW medium supplemented with $150 \mathrm{ml} / \mathrm{l}$ coconut water, $100 \mathrm{~g} / \mathrm{l}$ banana, $10 \mathrm{~g} / 1$ sucrose, $0.7 \mathrm{~g} / \mathrm{l}$ activated charcoal, $8 \mathrm{~g} / \mathrm{l}$ agar, and $\mathrm{pH}$ at 5.2. They were cultured at $25 \pm 3{ }^{\circ} \mathrm{C}$ under illumination of about $37 \mu \mathrm{mol} / \mathrm{m}^{2} / \mathrm{s}$ provided by fluorescent tubes (Philips, Thailand) for $16 \mathrm{~h} / \mathrm{d}$. Shoot tips excised from plantlets were used in these experiments.

\section{Effects of media and sucrose concentrations on shoot and root formations}

For shoot and root formations, modified Vacin and Went $^{5}(\mathrm{VW})$ or Murashige and Skoog ${ }^{6}$ (MS) media were used as basal medium. Shoot tips of $2-3 \mathrm{~mm}$ were excised under a stereo microscope from 2$3 \mathrm{~cm}$ long in vitro plantlets and placed on the culture medium. Various sucrose concentrations at $0,5,10$, 15,20 , and $30 \mathrm{~g} / 1$ were used as a carbon source. Shoot tips were cultured under the same conditions as previously described.

\section{Effects of BA, TDZ, and NAA on shoot and root formations}

Based on the results of the experiments, the most suitable medium and sucrose concentration were selected, and used for further investigation. The effects of BA, TDZ, and NAA alone or in combination with NAA were investigated. Shoot tips were cultured on the medium supplemented with BA at 1,3 , and $5 \mathrm{mg} / \mathrm{l}$, TDZ at $0.1,1,2$, and $4 \mathrm{mg} / \mathrm{l}$, and NAA at 0.5 and $1.0 \mathrm{mg} / \mathrm{l}$, each alone or in combination with NAA at 0.5 and $1.0 \mathrm{mg} / \mathrm{l}$. Shoot tips were cultured under the same conditions as previously described.

\section{Plant regeneration and transfer to the greenhouse}

After 6 months of culture, shoots produced roots were separated and then cultured on modified VW medium. In vitro plantlets with $2-3 \mathrm{~cm}$ in height, $2-$ 3 leaves, and 2-3 roots were removed from bottles. The plantlets were washed in water and transferred into pots filled with osmunda (tree fern fibre) in the greenhouse. Ten plantlets were planted in each pot. The survival rate was recorded after 3 months of culture in the greenhouse.

\section{Ploidy stability analysis using flow cytometry (FCM)}

To analyse ploidy stability, nuclei were isolated by chopping the leaves $(0.5 \times 0.5 \mathrm{~cm})$ of plantlets developed from all treatments in $200 \mu \mathrm{l}$ of nucleic acid extraction buffer following the addition of $1 \mathrm{ml}$ DAPI solution $(10 \mathrm{mM}$ Tris, $50 \mathrm{mM}$ sodium citrate, $2 \mathrm{mM} \mathrm{MgCl}_{2}, 0.1 \%(\mathrm{w} / \mathrm{v})$ polyvinyl pyrrolidone (PVP), 0.1\% (v/v) Triton X-100, $2 \mathrm{mg} / \mathrm{l}$ 4,6-diamidino-2-phenylindole (DAPI), $\mathrm{pH}$ at 7.5). After chopping the leaves, the suspension was filtered through $20 \mu \mathrm{m}$ mesh size nylon filter. Nuclei were analysed with a flow cytometer (Partec Cell Analyzer, Germany) ${ }^{7}$. All chemicals used in this study were analytical grade.

\section{Data collection and statistical analysis}

After 3 months of culture, survival rate, number of shoots per explant, number of shoot buds per explant, size of protocorm-like bodies, number of roots per explant, number of leaves per explant, plantlet height, and root formation were recorded. Twenty explants were used for each treatment. The experiments were replicated twice and the mean standard errors of the results were calculated. Experiments were organized according to a completely randomized design. Data were subjected to ANOVA (using SPSS 17 for windows) and the means were compared using Duncan's test.

\section{RESULTS}

\section{Effects of media and sucrose concentrations on shoot and root formations}

The shoot tips were able to grow on either modified VW or MS media. Significant differences were observed between media and sucrose concentrations for survival rate, number of shoots per explant, size of protocorm-like bodies, root formation, number of roots per explant, number of leaves per explant, and plantlet height (Table 1).

After 3 months of culture, the survival rate of shoot tips cultured on modified VW and MS media was about $50-87 \%$ and $\leqslant 40 \%$, respectively. The highest number of shoots (2 shoots/explant), root formation (100\%), number of roots (2.3 roots/shoot), and plantlet height $(0.8 \mathrm{~cm})$ were observed on modified VW medium supplemented with $10 \mathrm{~g} / \mathrm{l}$ sucrose (Table 1). Shoot tips grown on MS medium formed protocorm-like bodies and the size of protocormlike bodies was increased when sucrose concentration decreased on MS medium and had the highest size of $0.7 \mathrm{~cm}$ in the MS medium without sucrose. Shoot tips grown on modified VW medium did not form protocorm-like bodies at any sucrose concentration (Table 1).

Effects of sucrose concentrations were observed on the root formation. Rooting occurred on modified VW medium supplemented with and without sucrose while plantlets grew on MS medium without sucrose did not produce any roots (Table 1). Modified VW 
Table 1 Effects of modified VW and MS media and sucrose concentrations on shoot and root formations through in vitro shoot tips of $V$. coerulea after 3 months of culture.

\begin{tabular}{ccccccccc}
\hline Medium & $\begin{array}{c}\text { Sucrose } \\
(\mathrm{g} / \mathrm{l})\end{array}$ & $\begin{array}{c}\text { Survival rate } \\
(\%)\end{array}$ & $\begin{array}{c}\text { Number of } \\
\text { shoots per } \\
\text { explant }\end{array}$ & $\begin{array}{c}\text { Size of } \\
\text { protocorm-like } \\
\text { bodies }(\mathrm{cm})\end{array}$ & $\begin{array}{c}\text { Root } \\
\text { formation } \\
(\%)\end{array}$ & $\begin{array}{c}\text { Number of } \\
\text { roots per } \\
\text { explant }\end{array}$ & $\begin{array}{c}\text { Number of } \\
\text { leaves per } \\
\text { explant }\end{array}$ & $\begin{array}{c}\text { Plantlet } \\
\text { height }\end{array}$ \\
\hline VW & 0 & $56.7 \pm 9.2^{\mathrm{bc}}$ & $1.1 \pm 0.1^{\mathrm{bc}}$ & $0^{\mathrm{e}}$ & $88.2 \pm 8.1^{\mathrm{a}}$ & $2.0 \pm 0.3^{\mathrm{ab}}$ & $3.1 \pm 0.2^{\mathrm{a}}$ & $0.4 \pm 0.1^{\mathrm{bc}}$ \\
& 5 & $50.0 \pm 9.3^{\mathrm{c}}$ & $1.0 \pm 0.0^{\mathrm{bc}}$ & $0^{\mathrm{e}}$ & $73.3 \pm 11.8^{\mathrm{b}}$ & $1.8 \pm 0.4^{\mathrm{ab}}$ & $2.7 \pm 0.3^{\mathrm{ab}}$ & $0.4 \pm 0.1^{\mathrm{bc}}$ \\
& 10 & $75.0 \pm 9.3^{\mathrm{b}}$ & $2.0 \pm 0.1^{\mathrm{a}}$ & $0^{\mathrm{e}}$ & $100.0 \pm 0.0^{\mathrm{a}}$ & $2.3 \pm 0.3^{\mathrm{a}}$ & $2.9 \pm 0.1^{\mathrm{ab}}$ & $0.8 \pm 0.1^{\mathrm{a}}$ \\
& 15 & $86.7 \pm 6.3^{\mathrm{a}}$ & $1.0 \pm 0.0^{\mathrm{bc}}$ & $0^{\mathrm{e}}$ & $96.2 \pm 3.9^{\mathrm{a}}$ & $2.1 \pm 0.2^{\mathrm{ab}}$ & $2.9 \pm 0.2^{\mathrm{ab}}$ & $0.7 \pm 0.1^{\mathrm{ab}}$ \\
& 20 & $80.0 \pm 7.4^{\mathrm{ab}}$ & $1.3 \pm 0.1^{\mathrm{b}}$ & $0^{\mathrm{e}}$ & $75.0 \pm 9.0^{\mathrm{b}}$ & $1.8 \pm 0.3^{\mathrm{ab}}$ & $2.3 \pm 0.2^{\mathrm{ab}}$ & $0.5 \pm 0.1^{\mathrm{b}}$ \\
& 30 & $86.7 \pm 6.3^{\mathrm{a}}$ & $1.0 \pm 0.0^{\mathrm{bc}}$ & $0^{\mathrm{e}}$ & $88.2 \pm 8.1^{\mathrm{a}}$ & $2.0 \pm 0.3^{\mathrm{ab}}$ & $3.1 \pm 0.2^{\mathrm{a}}$ & $0.4 \pm 0.1^{\mathrm{bc}}$ \\
& 0 & $26.7 \pm 8.2^{\mathrm{d}}$ & $0.3 \pm 0.2^{\mathrm{c}}$ & $0.7 \pm 0.2^{\mathrm{a}}$ & $0.0^{\mathrm{e}}$ & $0^{\mathrm{c}}$ & $0.5 \pm 0.3^{\mathrm{c}}$ & $0.1 \pm 0.1^{\mathrm{d}}$ \\
& 5 & $40.0 \pm 9.1^{\mathrm{cd}}$ & $0.9 \pm 0.1^{\mathrm{bc}}$ & $0.1 \pm 0.1^{\mathrm{d}}$ & $83.3 \pm 11.2^{\mathrm{a}}$ & $1.1 \pm 0.3^{\mathrm{ab}}$ & $2.6 \pm 0.3^{\mathrm{ab}}$ & $0.3 \pm 0.0^{\mathrm{c}}$ \\
& 10 & $33.3 \pm 8.8^{\mathrm{cd}}$ & $0.8 \pm 0.1^{\mathrm{bc}}$ & $0.2 \pm 0.1^{\mathrm{c}}$ & $70.0 \pm 15.3^{\mathrm{b}}$ & $1.2 \pm 0.3^{\mathrm{ab}}$ & $2.8 \pm 0.5^{\mathrm{ab}}$ & $0.4 \pm 0.1^{\mathrm{bc}}$ \\
& 15 & $16.7 \pm 6.9^{\mathrm{de}}$ & $1.0 \pm 0.3^{\mathrm{bc}}$ & $0.3 \pm 0.3^{\mathrm{b}}$ & $40.0 \pm 24.5^{\mathrm{d}}$ & $0.8 \pm 0.6^{\mathrm{b}}$ & $2.6 \pm 0.9^{\mathrm{ab}}$ & $0.5 \pm 0.2^{\mathrm{b}}$ \\
& 20 & $26.7 \pm 8.2^{\mathrm{d}}$ & $1.4 \pm 0.3^{\mathrm{b}}$ & $0^{\mathrm{e}}$ & $75.0 \pm 16.4^{\mathrm{b}}$ & $1.8 \pm 0.5^{\mathrm{ab}}$ & $3.3 \pm 0.3^{\mathrm{a}}$ & $0.6 \pm 0.1^{\mathrm{ab}}$ \\
& 30 & $26.7 \pm 8.2^{\mathrm{d}}$ & $1.4 \pm 0.3^{\mathrm{b}}$ & $0^{\mathrm{e}}$ & $75.0 \pm 16.4^{\mathrm{b}}$ & $1.8 \pm 0.5^{\mathrm{ab}}$ & $3.3 \pm 0.3^{\mathrm{a}}$ & $0.6 \pm 0.1^{\mathrm{ab}}$ \\
\hline
\end{tabular}

Mean \pm standard error. In each column, similar letters mean no significant difference at $p \leqslant 0.05$ by Duncan's test.

medium supplemented with $150 \mathrm{ml} / \mathrm{l}$ coconut water, $100 \mathrm{~g} / \mathrm{l}$ banana and $0.7 \mathrm{~g} / \mathrm{l}$ activated charcoal induced root formation. The results showed that activated charcoal adsorbed phenolic compounds on modified VW medium. The colour of MS medium changed from white to brown after culturing plantlets for 3 months. Such change was not seen on modified VW medium.

\section{Effects of BA, TDZ, and NAA on shoot and root formations}

Significant differences were observed among concentrations of BA, TDZ, and NAA used alone or in combination with NAA for survival rate, number of shoot buds, number of shoots (Table 2), root formation, number of roots, number of leaves, and plantlet height (Table 3).

The highest survival rate $(97.5 \%)$ was observed when shoot tips were cultured on modified VW medium supplemented with $1 \mathrm{mg} / \mathrm{l}$ BA in combination with $0.5 \mathrm{mg} / \mathrm{l} \mathrm{NAA}$ (Table 2). Modified VW medium supplemented with NAA or TDZ alone and TDZ in combination with NAA have induced shoot buds from shoot tips after 3 months of culture but the frequency of shoot buds and shoot formation was less when compared to medium supplemented with BA (Fig. 1a). No significant differences of shoot formation when shoot tips were cultured on modified VW medium supplemented with $1 \mathrm{mg} / \mathrm{l} \mathrm{BA}$ and $2 \mathrm{mg} / \mathrm{l} \mathrm{TDZ}$ in combination with $0.5 \mathrm{mg} / \mathrm{l} \mathrm{NAA}$ but the highest number of shoot buds (8.7 shoot buds/explant) (Fig. 1b) and number of shoots (5.3 shoots/explant) were observed
Table 2 Effects of BA, TDZ, and NAA on \% response and morphogenesis through in vitro derived shoot tips of $V$. coerulea on modified VW medium after 3 months of culture.

\begin{tabular}{|c|c|c|c|c|c|}
\hline \multicolumn{3}{|c|}{$\begin{array}{l}\text { Plant growth } \\
\text { regulator }(\mathrm{mg} / \mathrm{l})\end{array}$} & \multirow[t]{2}{*}{$\begin{array}{l}\text { Survival rate } \\
\qquad \%)\end{array}$} & \multirow{2}{*}{$\begin{array}{l}\text { Number of } \\
\text { shoot buds } \\
\text { per explant }\end{array}$} & \multirow{2}{*}{$\begin{array}{c}\text { Number of } \\
\text { shoots per } \\
\text { explant }\end{array}$} \\
\hline$\overline{\mathrm{BA}}$ & NAA & TDZ & & & \\
\hline- & - & - & $75.0 \pm 6.9^{\mathrm{b}}$ & $2.2 \pm 1.2^{\mathrm{bc}}$ & $2.0 \pm 0.3^{\mathrm{cd}}$ \\
\hline 1.0 & - & - & $75.0 \pm 6.9^{\mathrm{b}}$ & $8.7 \pm 3.9^{\mathrm{a}}$ & $5.3 \pm 1.0^{\mathrm{a}}$ \\
\hline 3.0 & - & - & $67.5 \pm 7.5^{\mathrm{cd}}$ & $0.9 \pm 0.8^{\mathrm{cd}}$ & $3.7 \pm 1.1^{\mathrm{ab}}$ \\
\hline 5.0 & - & - & $90.0 \pm 4.8^{\mathrm{ab}}$ & $0.7 \pm 0.4^{\mathrm{d}}$ & $2.2 \pm 0.4^{\mathrm{c}}$ \\
\hline- & 0.5 & - & $95.0 \pm 3.5^{\mathrm{a}}$ & $0.9 \pm 0.6^{\mathrm{cd}}$ & $2.5 \pm 0.3^{b c}$ \\
\hline- & 1.0 & - & $75.0 \pm 6.9^{\mathrm{b}}$ & $0.7 \pm 0.5^{\mathrm{d}}$ & $2.2 \pm 0.4^{\mathrm{c}}$ \\
\hline - & - & 0.1 & $87.5 \pm 5.3^{\mathrm{ab}}$ & $1.9 \pm 0.9^{\mathrm{c}}$ & $3.8 \pm 0.5^{\mathrm{ab}}$ \\
\hline - & - & 1.0 & $70.0 \pm 7.3^{\mathrm{c}}$ & $1.4 \pm 0.7^{\mathrm{c}}$ & $2.3 \pm 0.4^{\mathrm{c}}$ \\
\hline- & - & 2.0 & $70.0 \pm 7.3^{\mathrm{c}}$ & $0.6 \pm 0.3^{\mathrm{d}}$ & $2.8 \pm 0.6^{\mathrm{b}}$ \\
\hline- & - & 4.0 & $70.0 \pm 7.3^{c}$ & $0.2 \pm 0.1^{\mathrm{f}}$ & $1.7 \pm 0.2^{\mathrm{d}}$ \\
\hline 1.0 & 0.5 & - & $97.5 \pm 2.5^{\mathrm{a}}$ & $0.4 \pm 0.2^{\mathrm{de}}$ & $2.1 \pm 0.3^{c}$ \\
\hline 3.0 & 0.5 & - & $80.0 \pm 6.4^{\mathrm{ab}}$ & $3.5 \pm 1.9^{\mathrm{b}}$ & $2.7 \pm 0.4^{\mathrm{b}}$ \\
\hline 5.0 & 0.5 & - & $75.0 \pm 6.9^{\mathrm{b}}$ & $3.2 \pm 1.9^{\mathrm{b}}$ & $2.9 \pm 0.3^{\mathrm{b}}$ \\
\hline 1.0 & 1.0 & - & $75.0 \pm 6.9^{\mathrm{b}}$ & $3.5 \pm 2.0^{\mathrm{b}}$ & $2.4 \pm 0.4^{\mathrm{c}}$ \\
\hline 3.0 & 1.0 & - & $80.0 \pm 6.4^{\mathrm{ab}}$ & $1.3 \pm 0.9^{c}$ & $2.6 \pm 0.4^{\mathrm{bc}}$ \\
\hline 5.0 & 1.0 & - & $77.5 \pm 6.7^{\mathrm{ab}}$ & $3.1 \pm 1.6^{\mathrm{b}}$ & $2.8 \pm 0.4^{\mathrm{b}}$ \\
\hline- & 0.5 & 0.1 & $72.5 \pm 7.2^{\mathrm{bc}}$ & $2.2 \pm 1.1^{\mathrm{bc}}$ & $2.8 \pm 0.4^{\mathrm{b}}$ \\
\hline- & 0.5 & 1.0 & $72.5 \pm 7.2^{\mathrm{bc}}$ & $0.4 \pm 0.1^{\mathrm{de}}$ & $1.8 \pm 0.3^{\mathrm{d}}$ \\
\hline - & 0.5 & 2.0 & $92.5 \pm 4.2^{\mathrm{ab}}$ & $1.6 \pm 0.7^{\mathrm{c}}$ & $4.9 \pm 0.9^{\mathrm{a}}$ \\
\hline - & 0.5 & 4.0 & $87.5 \pm 5.3^{\mathrm{ab}}$ & $0.7 \pm 0.1^{\mathrm{d}}$ & $1.4 \pm 0.2^{\mathrm{c}}$ \\
\hline- & 1.0 & 0.1 & $80.0 \pm 6.4^{\mathrm{ab}}$ & $0.3 \pm 0.2^{\mathrm{e}}$ & $2.5 \pm 0.4^{\mathrm{bc}}$ \\
\hline - & 1.0 & 1.0 & $82.5 \pm 6.1^{\mathrm{ab}}$ & $0.3 \pm 0.2^{\mathrm{e}}$ & $1.9 \pm 0.4^{\mathrm{cd}}$ \\
\hline - & 1.0 & 2.0 & $67.5 \pm 7.5^{\mathrm{cd}}$ & $1.0 \pm 0.7^{\mathrm{c}}$ & $2.5 \pm 0.5^{\mathrm{bc}}$ \\
\hline- & 1.0 & 4.0 & $85.0 \pm 5.7^{\mathrm{ab}}$ & $0.6 \pm 0.3^{\mathrm{d}}$ & $2.3 \pm 0.5^{\mathrm{c}}$ \\
\hline
\end{tabular}

Mean \pm standard error. In each column, similar letters mean no significant difference at $p \leqslant 0.05$ by Duncan's test.

on modified VW medium supplemented with $1 \mathrm{mg} / \mathrm{l}$ BA (Fig. 1c). 

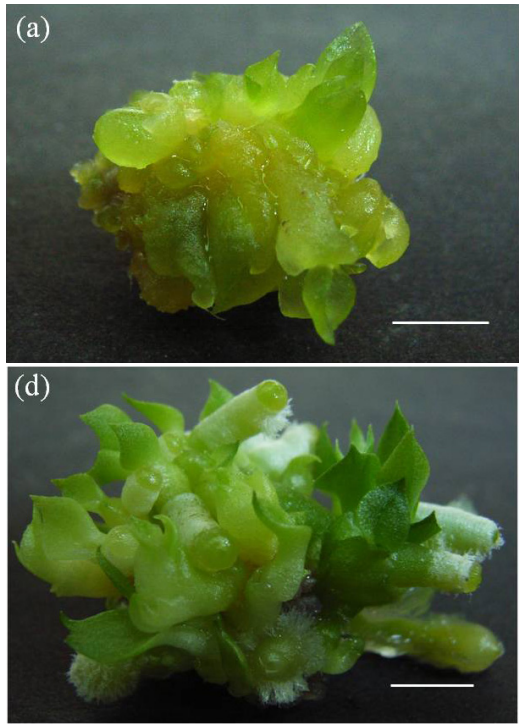
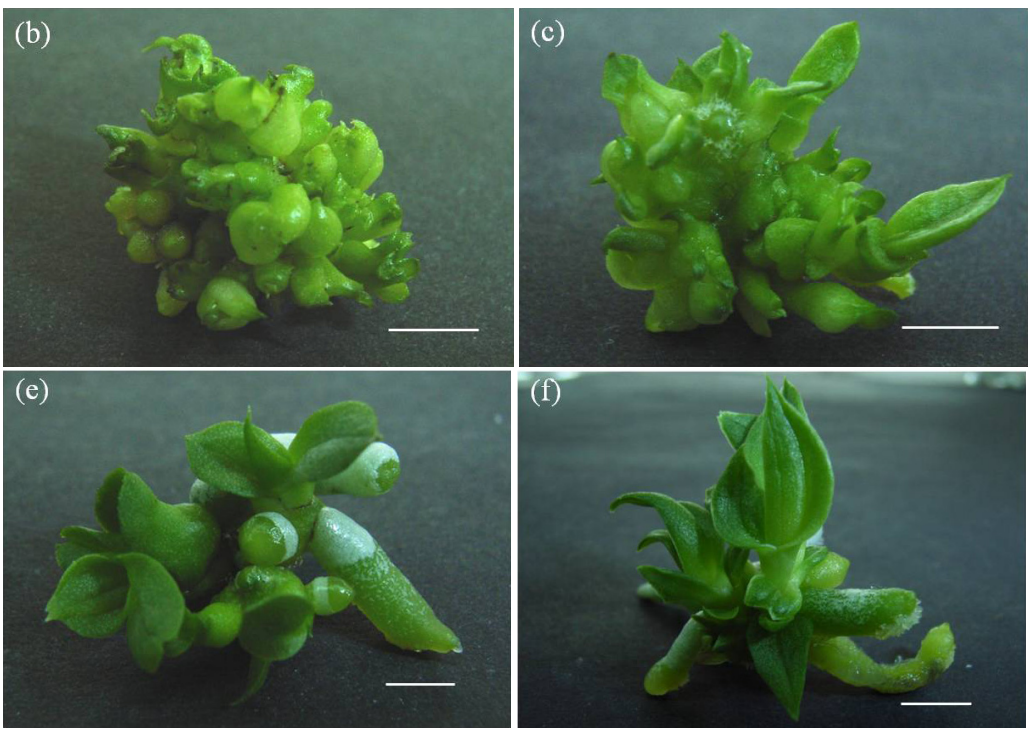

Fig. 1 Development of $V$. coerulea plantlets through in vitro shoot tips. A shoot tip formed shoot buds after (a) 4 weeks, (b) 6 weeks, and (c) 8 weeks of culture on modified VW medium supplemented with $1 \mathrm{mg} / \mathrm{l} \mathrm{BA}$. Roots induced through in vitro shoot tips were cultured on modified VW medium supplemented the combination of $0.5 \mathrm{mg} / \mathrm{l} \mathrm{NAA}$ and $2 \mathrm{mg} / \mathrm{l} \mathrm{TDZ}$ after (d) 9 weeks, (e) 10 weeks, and (f) 12 weeks of culture. Scale bar: $\mathrm{a}-\mathrm{f}=1 \mathrm{~cm}$.

BA concentrations above $3 \mathrm{mg} / \mathrm{l}$ reduced shoot buds and shoot formation (Table 2). The combination of BA with NAA inhibited shoot formation but increased shoot bud formation when compared to BA alone. These results showed that higher TDZ concentration reduced shoot regeneration. A lower concentration of TDZ $(0.1 \mathrm{mg} / \mathrm{l})$ induced high frequency of shoot regeneration (3.8 shoots/explant). The combination of $2 \mathrm{mg} / \mathrm{l} \mathrm{TDZ}$ with $0.5 \mathrm{mg} / \mathrm{l} \mathrm{NAA}$ induced higher formation of shoots (4.9 shoots/explant) than TDZ or NAA alone. The highest plantlet $(3.0 \mathrm{~cm})$ was observed on modified VW medium without plant growth regulator.

TDZ can be used at a lower concentration than BA. TDZ produced shoots at concentration below $1 \mathrm{mg} / \mathrm{l}$. In the rooting, shoots produced roots on modified VW medium in all treatments (Table 3). The number of shoots produced roots $(62.2 \%)$ were observed when shoot tips were cultured on modified VW medium supplemented with $2 \mathrm{mg} / \mathrm{l} \mathrm{TDZ}$ in combination with $0.5 \mathrm{mg} / \mathrm{l} \mathrm{NAA}$, number of roots/shoot was 2.5 roots/shoot (Fig. 1c-f). These results showed that activated charcoal induced root formation without adding plant growth regulator (control group).

\section{Plant regeneration and ploidy level stability}

After 3 months of culture, shoots produced roots, they were separated and cultured on modified VW medium without plant growth regulator. The size of
Table 3 Effects of BA, TDZ, and NAA on root formation and growth of plantlets through in vitro shoot tips of $V$. coerulea on modified VW medium after 3 months of culture.

\begin{tabular}{|c|c|c|c|c|c|c|}
\hline \multicolumn{3}{|c|}{$\begin{array}{l}\text { Plant growth } \\
\text { regulator }(\mathrm{mg} / \mathrm{l})\end{array}$} & \multirow{2}{*}{$\begin{array}{l}\text { Root } \\
\text { formation } \\
(\%)\end{array}$} & \multirow{2}{*}{$\begin{array}{l}\text { Number of } \\
\text { roots per } \\
\text { explant }\end{array}$} & \multirow{2}{*}{$\begin{array}{l}\text { Number of } \\
\text { leaves per } \\
\text { explant }\end{array}$} & \multirow{2}{*}{$\begin{array}{l}\text { Plantlet } \\
\text { height } \\
(\mathrm{cm})\end{array}$} \\
\hline $\mathrm{BA}$ & NAA & TDZ & & & & \\
\hline - & - & - & $.0 \pm 7$ & $0.8 \pm 0.3^{\mathrm{c}}$ & $0.3 \pm 0.1^{\mathrm{a}}$ & $3.0 \pm 0.02^{\mathrm{a}}$ \\
\hline 1.0 & - & - & $.7 \pm c$ & & $0.3 \pm 0.1^{\mathrm{c}}$ & $2.7 \pm$ \\
\hline 3.0 & - & - & & & & $0 \pm 0.02^{\mathrm{a}}$ \\
\hline 5.0 & - & - & $19.4 \pm 6.7^{\mathrm{d}}$ & $0.8 \pm 0.5^{\mathrm{c}}$ & $0.4 \pm 0.1^{\mathrm{b}}$ & $2.9 \pm 0.02^{\mathrm{ab}}$ \\
\hline- & 0.5 & - & $21.1 \pm 6.7^{\mathrm{d}}$ & $1.0 \pm 0.4^{\mathrm{c}}$ & $0.5 \pm 0.1^{\mathrm{a}}$ & $2.8 \pm 0.1^{\mathrm{b}}$ \\
\hline - & 1.0 & - & $3.3 \pm 6.3^{\mathrm{de}}$ & $0.8 \pm 0.5^{\mathrm{c}}$ & $0.4 \pm 0.1^{\mathrm{b}}$ & $3.0 \pm 0.02^{\mathrm{a}}$ \\
\hline - & - & 0.1 & $28.6 \pm 7$ & $1.0 \pm 0.4^{\mathrm{c}}$ & $0.5 \pm 0.2^{\mathrm{a}}$ & $2.6 \pm 0.03^{\mathrm{c}}$ \\
\hline - & - & 1.0 & $21.4 \pm 7$ & $0.4 \pm 0.2^{\text {cd }}$ & $0.4 \pm 0.1^{\mathrm{b}}$ & $3.0 \pm 0.02^{\mathrm{a}}$ \\
\hline- & - & 2.0 & $28.6 \pm 8.7^{\mathrm{cd}}$ & $1.0 \pm 0.4^{c}$ & $0.5 \pm 0.1^{\mathrm{a}}$ & $3.0 \pm 0.02^{\mathrm{a}}$ \\
\hline - & - & 4.0 & $21.4 \pm 7.9^{\mathrm{d}}$ & $0.8 \pm 0.3^{c}$ & $0.4 \pm 0.1^{\mathrm{b}}$ & $2.9 \pm 0.02^{\mathrm{ab}}$ \\
\hline 1.0 & 0.5 & - & $10.3 \pm 4$ & $1.3 \pm 0.4^{\mathrm{b}}$ & $0.4 \pm$ & $3.0 \pm 0.02^{\mathrm{a}}$ \\
\hline 3.0 & 0.5 & - & $37.5 \pm 8.7^{\mathrm{c}}$ & $1.0 \pm 0.3^{\mathrm{b}}$ & $0.4 \pm 0.1^{\mathrm{b}}$ & $2.8 \pm 0.02^{\mathrm{b}}$ \\
\hline 5.0 & 0. & - & $50.0 \pm 9.3^{\mathrm{ab}}$ & $1.5 \pm 0.3^{\mathrm{ab}}$ & $0.4 \pm 0.1^{\mathrm{b}}$ & $2.6 \pm 0.02^{\mathrm{c}}$ \\
\hline 1.0 & 1.0 & - & $53.3 \pm 9.3^{\mathrm{ab}}$ & $1.6 \pm 0.4^{\mathrm{ab}}$ & $0.4 \pm 0.1^{\mathrm{b}}$ & $2.8 \pm 0.02^{\mathrm{b}}$ \\
\hline 3.0 & 1.0 & - & $28.1 \pm$ & $0.8 \pm 0.2^{c}$ & & $2.6 \pm 0.02^{\mathrm{c}}$ \\
\hline 5.0 & 1.0 & - & $41.9 \pm 9.0^{\mathrm{bc}}$ & $1.1 \pm 0.3^{b}$ & $0.4 \pm 0.1^{\mathrm{b}}$ & $2.7 \pm 0.02^{\mathrm{bc}}$ \\
\hline- & 0.5 & 0.1 & $48.3 \pm 9.4^{\mathrm{b}}$ & $1.1 \pm 0.3^{b}$ & $0.4 \pm 0.1^{\mathrm{b}}$ & $2.7 \pm 0.02^{\mathrm{bc}}$ \\
\hline - & 0.5 & 1.0 & $37.9 \pm 9.2^{\mathrm{c}}$ & $0.9 \pm 0.3^{\mathrm{bc}}$ & $0.5 \pm 0.1^{\mathrm{a}}$ & $2.8 \pm 0.02^{\mathrm{b}}$ \\
\hline- & 0.5 & 2.0 & $62.2 \pm 8.1^{\mathrm{a}}$ & $2.5 \pm 0.5^{\mathrm{a}}$ & $0.4 \pm 0.1^{\mathrm{b}}$ & $2.5 \pm 0.02^{\mathrm{c}}$ \\
\hline- & 0.5 & 4.0 & $11.4 \pm 5.5^{\mathrm{de}}$ & $0.2 \pm 0.1^{\mathrm{d}}$ & $0.5 \pm 0.1^{\mathrm{a}}$ & $2.7 \pm 0.01^{\mathrm{bc}}$ \\
\hline- & 1.0 & 0.1 & $21.9 \pm 7.4^{\mathrm{d}}$ & $0.4 \pm 0.2^{\text {cd }}$ & $0.4 \pm 0.1^{\mathrm{b}}$ & $2.5 \pm 0.02^{\mathrm{c}}$ \\
\hline - & 1.0 & 1.0 & $30.3 \pm 8.1^{\mathrm{cd}}$ & $0.7 \pm 0.2^{c}$ & $0.5 \pm 0.1^{\mathrm{a}}$ & $2.8 \pm 0.02^{\mathrm{b}}$ \\
\hline - & 1.0 & 2.0 & $44.4 \pm 9.8^{\mathrm{bc}}$ & $0.9 \pm 0.2^{\mathrm{c}}$ & $0.4 \pm 0.1^{\mathrm{b}}$ & $2.7 \pm 0.02^{\mathrm{bc}}$ \\
\hline- & 1.0 & 4.0 & $38.2 \pm 8.5^{\mathrm{c}}$ & $0.8 \pm 0.2^{\mathrm{c}}$ & $0.4 \pm 0.1^{\mathrm{b}}$ & $2.5 \pm 0.03^{\mathrm{c}}$ \\
\hline
\end{tabular}

Mean \pm standard error. In each column, similar letters mean no significant difference at $p \leqslant 0.05$ by Duncan's test. 


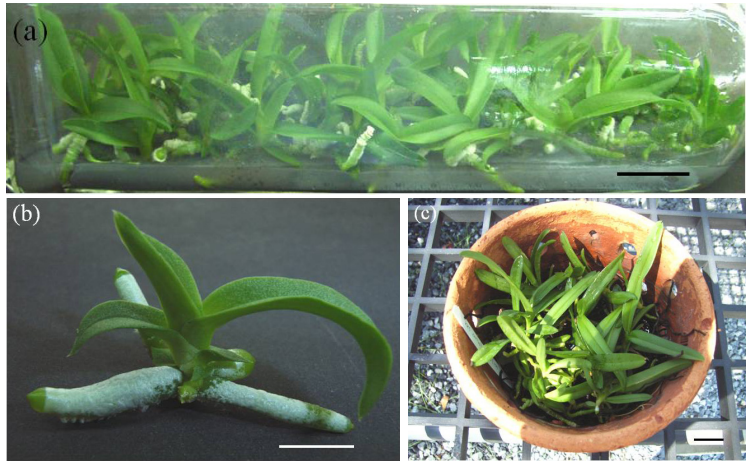

Fig. 2 Development of $V$. coerulea plantlets on modified VW medium without plant growth regulator. (a-b) after 2 months of culture. (c) 3-month-old plantlets grown in the greenhouse. Scale bar: $\mathrm{a}-\mathrm{c}=1 \mathrm{~cm}$.
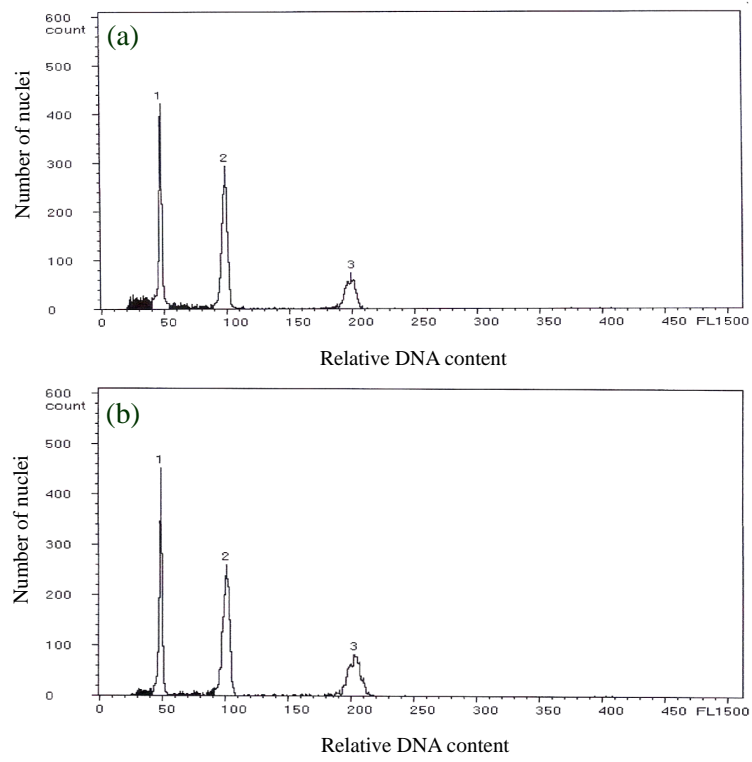

Fig. 3 Histogram showing ploidy levels in leaves of V. coerulea from (a) 6-month-old stock plants and (b) regenerated plants.

shoots increased after 1 month of culture and plantlets developed roots after 3 months of culture (Fig. 2a-b). The plantlets with $2-3 \mathrm{~cm}$ in height, $2-3$ leaves, and $2-3$ roots were removed from the bottle. The rooted shoots were washed in water and transplanted into pots filled with osmunda. Survival rate of plantlets after 3 months of culture in the greenhouse was 100\% (Fig. 2c). A similar pattern of ploidy level was detected by flow cytometry from the leaves of both stock plants and regenerated plants (Fig. 3).

\section{DISCUSSION}

There are many different media used for epiphytic orchid culture, such as MS, VW, Kundson (KC), and New Dogashima. Lakshmanan et $\mathrm{al}^{8}$ reported that the three basal media (VW, KC, and MS) were used and VW and $\mathrm{KC}$ were found to be equally suitable for thin section culture from shoot tip of hybrid Aranda Deborah. Carbon sources are added to the culture medium because of the light energy deficiency and low $\mathrm{CO}_{2}$ concentration presented conditions in vitro. Plant cultures in vitro often show a low photosynthetic rate and incomplete autotrophy ${ }^{9}$. Sugar acts as a carbon and energy source and acts as an osmotic regulator in the induction medium ${ }^{10}$. Sucrose is the most frequently used but glucose, fructose, sorbitol, maltose, and other sugars are also used ${ }^{11}$. Sucrose concentrations of $20-30 \mathrm{~g} / \mathrm{l}$ are the most commonly used in orchid tissue culture. The results showed that shoots can be regenerated from shoot tips on modified VW and MS medium. Modified VW medium supplemented with high sucrose concentration $(30 \mathrm{~g} / \mathrm{l})$ did not produce high number of new shoots, similar to reported proliferation and rooting of Pyrus syriaca in vitro ${ }^{12}$. In addition, high concentration of sucrose on MS medium increased shoots and number of roots. The presence of $60 \mathrm{~g} / \mathrm{l}$ sucrose in the medium was the most efficient for increasing height and fresh weight of Dendrobium nobile in vitro culture ${ }^{9}$. The presence of sucrose in the culture medium caused protocorm formation in Phalaenopsis ${ }^{13}$. The highest root formation was observed on the modified VW medium supplemented with $10 \mathrm{~g} / \mathrm{l}$ sucrose. The root formation was inhibited on modified VW medium supplemented with high sucrose concentrations. Increasing sucrose or fructose concentrations inhibited root formation of Pyrus syriaca ${ }^{12}$. In addition, root formation on MS medium required sucrose. Shoot tips of $V$. coerulea formed protocorm-like bodies on MS medium. The size of protocorm-like bodies was increased when sucrose concentration decreased on MS medium and had the highest size of $0.7 \mathrm{~cm}$ in the MS medium without sucrose. However, shoot tips grown on modified VW medium did not form protocorm-like bodies at all sucrose concentrations. The addition of $150 \mathrm{ml} / \mathrm{l}$ coconut water and $100 \mathrm{~g} / \mathrm{l}$ banana in modified VW medium induced shoot and root formations in vitro (control group). It was supported by the results of Sinha and Roy ${ }^{14}$. Activated charcoal in the medium enhanced the induction of roots ${ }^{15}$. In this study, the addition of activated charcoal on modified VW medium enhanced root formation without increasing sucrose or plant growth regulators. This is simi- 
lar to a previous study on shoot multiplication and rooting of some new banana cultivars ${ }^{16}$. Activated charcoal affects shoot proliferation, improves aeration and adsorbs ethylene which can inhibit growth and proliferation $^{17}$.

Two main groups of plant growth regulator are used in media for plant culture. These are cytokinins and auxins ${ }^{18,19}$. Types and concentrations of cytokinins (BA and TDZ) and concentrations of NAA affected shoot and root formations of $V$. coerulea. Low concentrations of cytokinins (1-3 mg/l BA) increased shoot buds and shoot formation, but $5 \mathrm{mg} / \mathrm{l} \mathrm{BA}$ decreased shoot and root formations of $V$. coerulea. Previously, Seeni and Latha ${ }^{3}$ reported that the combination of $2 \mathrm{mg} / \mathrm{l} \mathrm{BA}$ and $0.76 \mathrm{mg} / \mathrm{l} \mathrm{NAA}$ induced shoot formation from $V$. coerulea leaves. TDZ is a substituted phenyl urea with cytokinin-like activity. It is useful for plant regeneration of several species through organogenesis and promotes shoot formation in vitro shoot formation in several orchid species ${ }^{20}$. TDZ was efficient to induce direct somatic embryogenesis from leaf explants but it was ineffective to induce somatic embryogenesis from root of Oncidium $^{21,22}$. TDZ alone or in combination with auxins has been used to induce embryogenesis in Cymbidium ensifolium $^{23}$, Oncidium $^{22}$, protocorm-like bodies in Doritaenopsis $^{24}$ and Doritaenopsis hybrid ${ }^{25}$. The results suggested that $0.1 \mathrm{mg} / \mathrm{l} \mathrm{TDZ}$ induced high shoot formation from shoot tips of $V$. coerulea. TDZ concentration higher than $0.1 \mathrm{mg} / \mathrm{l}$ reduced shoot formation, as has been reported for Doritaenopsis hybrid $^{24}$ and Cymbidium sinense ${ }^{26}$. Comparing the effects of BA and TDZ at different levels on shoot formation of $V$. coerulea, it was found that TDZ can be used at a much lower concentration than BA, in agreement with a previous study ${ }^{25}$. In this study, not only shoots could be promoted from shoot tips, but also roots were formed simultaneously from shoots in all treatments. The combination of $0.5 \mathrm{mg} / \mathrm{l} \mathrm{NAA}$ and $2 \mathrm{mg} / \mathrm{l} \mathrm{TDZ}$ was found to be the best for number of roots per explant of $V$. coerulea. In contrast, rooting V. coerulea shoots occurred in Mitra, Prasad, and Roy medium $^{2}$ containing $35 \mathrm{~g} / \mathrm{l}$ banana pulp and $1.08 \mu \mathrm{M}$ NAA within 3-4 weeks ${ }^{3}$. Cultured thin $V$. coerulea shoot tip sections on VW medium supplemented with 11.35 $\mu \mathrm{M}$ TDZ did produce protocorm-like bodies that later develop into shoots with 2-3 leaves, but the shoots produced roots when cultured on half strength VW medium supplemented with $11.42 \mu \mathrm{M} \mathrm{IAA}^{4}$, these methods did not produce shoots and roots from the same medium. Nuclei isolated from leaves of stock plants and regenerated plants of $V$. coerulea did not have the effect on ploidy levels of $V$. coerulea detected by flow cytometry, and no morphological variation between stock plants and regenerated plants of $V$. coerulea plantlets developed from shoot tips was observed.

Acknowledgments: This work was supported by Royal Golden Jubilee Ph.D. Program, Thailand Research Fund, Thailand. We thank Prof. Dr Masahiro Mii from Faculty of Horticulture, Chiba University for flow cytometry analysis and Japan Horticultural Production and Research Institute, Matsudo, Chiba, Japan for doing this study.

\section{REFERENCES}

1. Thammasiri K, Soamkul L (2007) Cryopreservation of Vanda coerulea Griff. ex Lindl. seeds by vitrification. Sci Asia 33, 223-7.

2. Mitra GC, Prasad RN, Roy CA (1976) Inorganic salts and differentiation of protocorms in seed callus of orchid correlative changes in its free amino acid content. Indian J Exp Biol 14, 350-1.

3. Seeni S, Latha PG (2000) In vitro multiplication and ecorehabilitation of the endangered Blue Vanda. Plant Cell Tissue Organ Cult 61, 1-8.

4. Malabadi RB, Mulgund GS, Nataraja K (2004) Efficient regeneration of Vanda coerulea, an endangered orchid using thidiazuron. Plant Cell Tissue Organ Cult 76, 289-93.

5. Vacin E, Went F (1949) Culture solution for orchid seedlings. Bot Gaz 110, 605-13.

6. Murashige T, Skoog F (1962) A revised medium for rapid growth and bio assays with tobacco tissue cultures. Physiol Plantarum 15, 473-97.

7. Hirano T, Godo T, Mii M, Ishikawa K (2005) Cryopreservation of immature seeds of Bletilla striata by vitrification. Plant Cell Rep 23, 534-9.

8. Lakshmanan P, Loh CS, Goh CJ (1995) An in vitro method for rapid regeneration of a monopodial orchid hybrid Aranda Deborah using thin section culture. Plant Cell Rep 14, 510-4.

9. Faria RT, Rodrigues FN, Oliveira LVR, Müller C (2004) In vitro Dendrobium nobile plant growth and rooting in different sucrose concentrations. Hort Bras 22, 780-3.

10. Indrianto A, Hererle BE, Touaev A (1990) Assessment of various stress and carbohydrates for their effects on the induction of embryogenesis isolated wheat microspores. Plant Sci 143, 71-9.

11. Sopalun K, Thammasiri K, Ishikawa K (2010) Micropropagation of the Thai orchid Grammatophyllum speciosum Blume. Plant Cell Tissue Organ Cult 101, 143-50.

12. Shatnawi MA, Shibli RA, Obedat AO, Ereifei K, Abdalleh MAE (2006) Influence of different carbon sources on wild pear (Pyrus syriaca) growth and sugar uptake. World J Agr Sci 2, 156-61.

13. Ishii Y, Takamura T, Goi M, Tanaka M (1998) Callus 
induction and somatic embryogenesis of Phalaenopsis. Plant Cell Rep 17, 446-50.

14. Sinha P, Roy SK (2004) Regeneration of an indigenous orchid, Vanda teres (Roxb) Lindl. through in vitro culture. Plant Tissue Cult 14, 55-61.

15. Bhadra SK, Hossain MM (2003) In vitro germination and micropropagation of Geodorum densiflorum (Lam.) Schltr., an endangered orchid species. Plant Tissue Cult 13, 165-71.

16. Gubbuk H, Pekmezci M (2004) In vitro propagation of some new banana types (Musa spp.). Turk J Agr Forest 28, 355-61.

17. Ernst R (1974) The use of activated charcoal in asymbiotic seedling culture of Paphiopedilum. Am Orchid Soc Bull 43, 35-8.

18. Chen T, Chen J, Chang W (2004) Plant regeneration through direct shoot bud formation from leaf cultures of Phalaenopsis orchids. Plant Cell Tissue Organ Cult 76, 11-5.

19. Wu I, Chen T, Chang W (2004) Effects of auxins and cytokinins on embryo formation from root-derived callus of Oncidium 'Gower Ramsey'. Plant Cell Tissue Organ Cult 77, 107-9.

20. Huetteman CA, Preece JE (1993) Thidiazuron: a potent cytokinin for woody plant tissue culture. Plant Cell Tissue Organ Cult 33, 105-19.

21. Chen J, Chang W (2000) Efficient plant regeneration through somatic embryogenesis from callus cultures of Oncidium (Orchidaceae). Plant Sci 160, 87-93.

22. Chen J, Chang W (2000) Plant regeneration via embryo and shoot bud formation from flower stalk explants of Oncidium Sweet Sugar. Plant Cell Tissue Organ Cult 62, 95-100.

23. Chang C, Chang WC (1998) Plant regeneration from callus culture of Cymbidium ensifolium var. misericors. Plant Cell Rep 17, 251-5.

24. Park SY, Murthy HN, Paek KY (2003) Protocormlike bodies induction and subsequent plant regeneration from root tip culture of Doritaenopsis. Plant Sci 164, 919-23.

25. Park SY, Yeung EC, Chakrabarty D (2002) An efficient direct induction of protocorm-like bodies from leaf sub epidermal cells of Doritaenopsis hybrid using thinsection culture. Plant Cell Rep 21, 46-51.

26. Chang C, Chang WC (2000) Effect of thidiazuron on bud development of Cymbidium sinense Wild in vitro. Plant Growth Regul 30, 171-5. 